\title{
Geomedia
}

Majalah Ilmiah dan Informasi Kegeografian

Geomedia Vol. 19 No. 1 Tahun 2021 | $46-53$

https://journal.uny.ac.id/index.php/geomedia/index

\section{Studi perbandingan sebaran spasial COVID-19 di Yogyakarta dan Gorontalo}

\author{
Nursida Arif a, ${ }^{1^{*}}$, Dyah Respati Suryo Sumunar ${ }^{\text {a, }}{ }^{2}$, Nurul Khotimah ${ }^{\text {a, }}{ }^{\text {, Etika Cahyani }}{ }^{\text {a, }}{ }^{\text {, }}$ \\ Yusuf Susena a, ${ }^{\text {, }}$ Riga Aditya Ariyanto ${ }^{\text {a, } 6}$ \\ a Unversitas Negeri Yogyakarta, Yogyakarta, Indonesia \\ ${ }^{1}$ nursida.arif@uny.ac.id*; dyah_respati@uny.ac.id; nurulkhotimah@uny.ac.id; etikacahyani.2017@student.uny.ac.id; \\ yusufsusena.2017@student.uny.ac.id; rigaaditya.2018@student.uny.ac.id \\ *korespondensi penulis
}

\begin{tabular}{ll}
\hline Informasi artikel \\
\hline $\begin{array}{ll}\text { Sejarah artikel } \\
\text { Diterima }\end{array}$ & $: 17$ April 2021 \\
Revisi & $: 06$ Mei 2021 \\
Dipublikasikan & $: 31$ Mei 2021 \\
\hline
\end{tabular}

\section{Kata kunci:}

COVID-19

Gorontalo

Yogyakarta

Suhu

\begin{abstract}
A B S T R A K
Perbedaan sebaran COVID-19 di berbagai negara masih menjadi isu yang terus dikaji karena banyak faktor yang mempengaruhinya. Salah satu faktor yang berkorelasi dengan penyebaran COVID-19 adalah faktor suhu. Indonesia merupakan negara kepulauan terbesar yang memiliki keunikan karena letak dan kondisi geografisnya. Penelitian melihat perbedaan sebaran COVID-19 di dua provinsi di Indonesia yaitu Yogyakarta dan Gorontalo. Secara geografis kedua wilayah ini sangat berbeda. Suhu pada masing-masing wilayah dilihat berdasarkan suhu permukaan lahan menggunakan citra satelit Landsat 8 . Suhu rata-rata tertinggi di provinsi Gorontalo yaitu $34,24^{\circ} \mathrm{C}$ terdistribusi di kota Gorontalo dan kabupaten Gorontalo. Sedangkan suhu tertinggi di DIY terdistribusi di kota Yogyakarta dengan suhu $32,72^{\circ} \mathrm{C}$. Berdasarkan data yang diperoleh Gorontalo merupakan salah satu provinsi di Indonesia yang terdampak paling akhir, namun memiliki memiliki persentase terpapar lebih besar yaitu $0,23 \%$ yaitu dibandingkan DIY 0,07\%. Sebaran spasial yang mengelompok diperkotaan menunjukkan bahwa mobilitas penduduk dapat menjadi pemicu meningkatnya jumlah kasus COVID-19. Sedangkan faktor-faktor yang diinvestigasi dalam penelitian ini yaitu suhu, lamanya waktu terpapar dan jumlah penduduk tidak menunjukkan pengaruh yang signifikan terhadap persebaran COVID-19.
\end{abstract}

A B S T R A C T
The difference in the contagious spreading of COVID-19 in various
countries is still an issue to be studied. Many factors influence it. One of
the factors is geographical factors. Indonesia is the largest archipelago
country which has a unique location and geographical conditions. This
study looks at the differences spreading of COVID-19 in two provinces in
Indonesia, namely Yogyakarta and Gorontalo. Geographically, these two
regions are very different. The temperature in each region were seen based
on the land surface temperature using Landsat 8 satellite imagery. The
highest average temperature in Gorontalo province is $34.24^{\circ} \mathrm{C}$, distributed
in Gorontalo city and Gorontalo district. Meanwhile, the highest
temperature in DIY is distributed in the city of Yogyakarta with a
temperature of $32.72^{\circ} \mathrm{C}$. Based on the data obtained, Gorontalo is one of
the most affected provinces in Indonesia, but has a greater percentage of
exposure, namely $0.23 \%$, compared to DIY $0.07 \%$. The spatial distribution
clustered in cities shows that population mobility can trigger an increase
in the number of COVID-19 cases. Meanwhile, the factors investigated in

\section{Keywords: \\ COVID-19 \\ Gorontalo \\ Yogyakarta \\ Temperature}


this study which are temperature, length of time of exposure, and population, did not show a significant effect on the spread of COVID-19.

(C) 2021 (Nursida Arif). All Right Reserved

\section{Pendahuluan}

Indonesia merupakan negara kepulauan dimana setiap pulaunya memiliki karakteristik yang berbeda sehingga menarik untuk diketahui sejauh mana kondisi tersebut mempengaruhi penyebaran COVID-19. Berdasarkan data per 27 April 2020 total ada 9.096 kasus COVID-19 di Indonesia dengan jumlah kematian 765 orang dengan sebaran terbanyak berada di pulau Jawa. Penelitian ini bertujuan untuk membandingkan penyebaran COVID-19 di Gorontalo dan Yogyakarta, Indonesia yang berbeda secara geografis.

Setiap lokasi memiliki iklim yang khas dan parameter geografis yang tidak berubah (Sun et al., 2020a). Faktor iklim merupakan salah satu faktor pengendali pada sejumlah kasus COVID-19 selain migrasi populasi (Wu et al., 2020). Beberapa penyakit pernapasan menyebar dengan cepat di lingkungan yang lebih dingin seperti influenza (Liu et al., 2018; Zhang et al., 2015). Berdasarkan analisis pada variabel iklim, ada bukti bahwa suhu mempengaruhi epidemi influenza di daerah tropis (Tamerius et al., 2013). Suhu yang meningkat adalah faktor lingkungan yang dikaitkan dengan penurunan tingkat kasus di China berdasarkan kasus COVID-19 yang dikonfirmasi setiap hari (Shi et al., 2020). Selain itu kepadatan penduduk dan kebiasaan masyarakat juga mempengaruhi penyebaran COVID-19 (Byass, 2020; Sun et al., 2020b).

Yogyakarta termasuk salah satu provinsi di Indonesia yang pertumbuhan populasinya sangat dinamis karena merupakan tujuan utama wisata serta pusat pendidikan dan budaya (Rana, Shreema \& Marwasta, 2015). Sehingga sangat memungkinkan transmisi penyebaran COVID-19 tidak terkontrol. Dalam beberapa penelitian terdahulu menyebutkan bahwa kepadatan populasi sangat berkorelasi dengan meningkatnya jumlah kasus COVID-19 (Hanibuchi et al., 2020; Sun et al., 2020a). Gorontalo dipilih menjadi wilayah perbandingan karena menjadi salah satu dari dua Provinsi di Indonesia yang terdampak paling akhir, bersama Provinsi Nusa Tenggara Timur (NTT). Kasus pertama di Gorontalo baru dikonfirmasi pada tanggal 10 April 2020.

\section{Metode \\ Study Area}

Daerah Istimewa Yogyakarta (DIY) terletak pada $7^{\circ} 47^{\prime} \mathrm{S}$ dan $110^{\circ} 22^{\prime} \mathrm{E}$, memiliki luas 3,133.15 $\mathrm{km}^{2}$ dengan 3,594,290 populasi (BPS-Statistik Daerah Istimewa Yogyakarta, 2020). Secara geografis DIY terletak ditengah-tengah pulau Jawa, dibagian utara terdapat Gunung Merapi yang merupakan salah satu gunung aktif di Indonesia, sedangkan bagian selatan terdapat dataran pantai yang terletak di pinggiran samudera Indonesia. Secara administrasi DIY terletak antara Kabupaten Klaten di sebelah Timur Laut, Kabupaten Wonogiri di sebelah Tenggara, kabupaten Purworejo di sebelah Barat, Kabupaten Magelang di seblah Barat Laut dan Samudera Indonesia di sebelah Selatan. DIY terdiri dari empat Kabupaten dan 1 Kota Madya yaitu Kabupaten Kulonprogo, Bantul, Gunung Kidul, Sleman dan Kota Yogyakarta.

Gorontalo terletak pada $0^{\circ} 19^{\prime}-0^{\circ} 57^{\prime} \mathrm{N}$ dan $121^{\circ} 23^{\prime}-125^{\circ} 14^{\prime} \mathrm{E}$, memiliki total luas wilayah $11.257,07 \mathrm{~km}^{2}(0,59 \%$ luas wilayah Indonesia) dengan total penduduk mencapai 1.202.631 jiwa (BPS Provinsi Gorontalo dalam Angka 2020). Provinsi Gorontalo memiliki lima kabupaten dan satu kota, yaitu Kabupaten Boalemo, Kabupaten Gorontalo, Kabupaten Pohuwato, Kabupaten Bone Bolango, Kabupaten Gorontalo Utara, dan Kota Gorontalo. Gorontalo memiliki kondisi geografis yang strategis, yaitu berbatasan langsung dengan Laut Sulawesi di utara dan Teluk Tomini di selatan. Secara administratif wilayah Gorontalo berbatasan dengan dua provinsi lain, yaitu Provinsi Sulawesi Tengah di sebelah barat dan Provinsi Sulawesi Utara di sebelah timur. 


\section{Analisis Data}

Pada penelitian ini data iklim hanya dilihat berdasarkan suhu permukaan lahan yang dianalisis citra Landsat 8 OLI rekaman tanggal 19 September 2019 untuk wilayah Gorontalo dan rekaman tanggal 25 Juni 2019 untuk wilayah DIY. Sedangkan jumlah kasus COVID-19 yang di analisis yaitu data sejak kasus pertama hingga tanggal 30 September 2020 menggunakan statistik dengan teknik analisis deskriptif. Data tingkat infeksi COVID-19 dihitung menggunakan persamaan:

Tingkat infeksi $=\left(\frac{\text { jumlah kasus }}{\text { jumlah hari terinfeksi }}\right)$

\section{Hasil dan pembahasan}

Suhu Permukaan Lahan

Parameter iklim dalam penelitian ini hanya berdasarkan suhu permukaan lahan karena merupakan faktor yang berperan besar dalam perubahan iklim global dan tata guna lahan (Arif et al., 2019; Ma et al., 2010). Hasil analisis suhu secara spasial di Gorontalo disajikan dalam Gambar 1 dan suhu di Yogyakarta disajikan pada Gambar 2. Gambar 1 menunjukkan suhu tertinggi di Gorontalo $34,24{ }^{\circ} \mathrm{C}$ dan terendah $21,02{ }^{\circ} \mathrm{C}$. Sedangkan Gambar 2 menunjukkan suhu tertinggi di Yogyakarta yaitu $34,32{ }^{\circ} \mathrm{C}$ dan suhu terendah $28,58^{\circ} \mathrm{C}$.

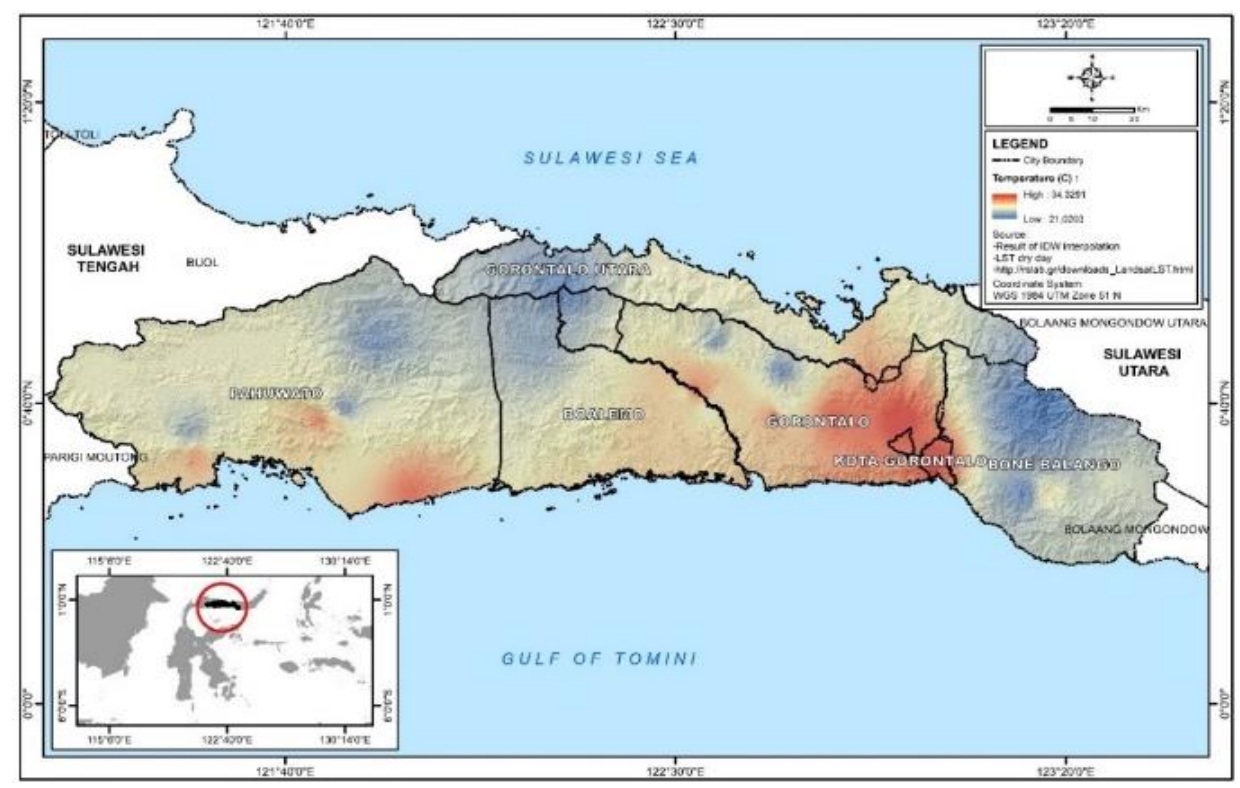

Gambar 1. Peta Suhu Gorontalo (Hasil Analisis Interpolasi, 2020)

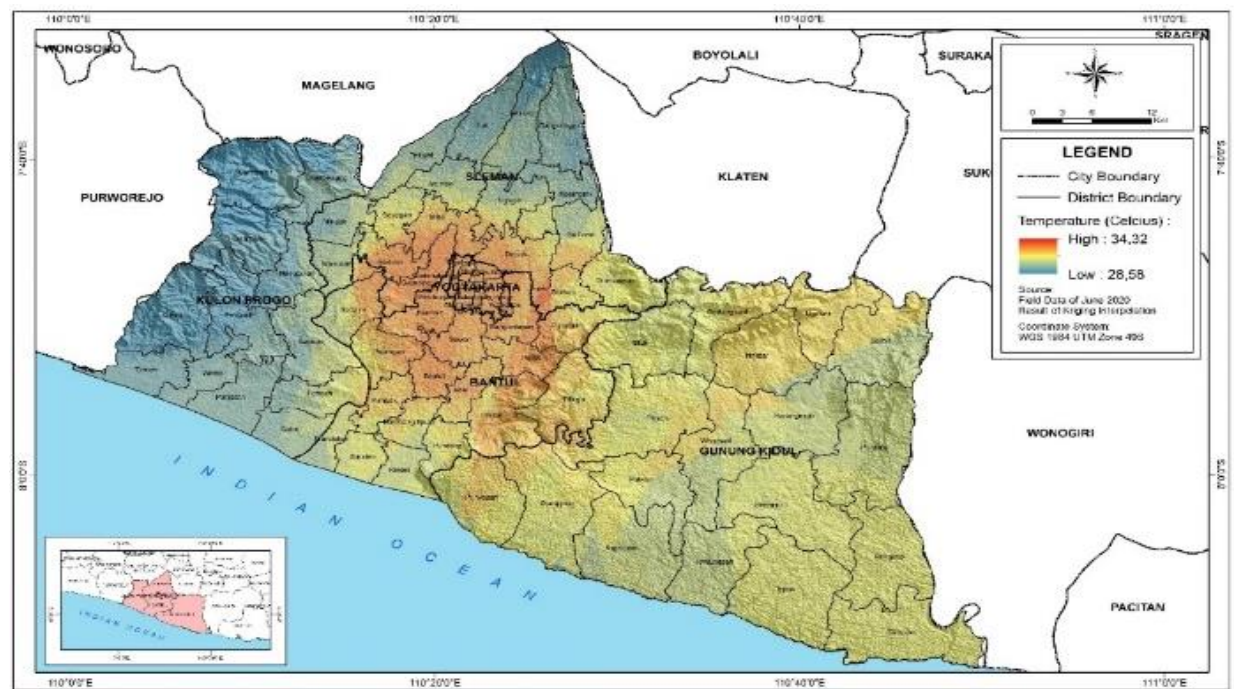

Gambar 2. Peta Suhu di DIY (Hasil Analisis Interpolasi, 2020) 
Kedua wilayah memiliki kesamaan pola distribusi spasial dimana pusat kota memiliki suhu yang lebih tinggi dibandingkan wilayah lainnya. $\mathrm{Hal}$ ini mengindikasikan jumlah lahan terbangun yang lebih banyak di perkotaan dibandingkan dengan non terbangun mempengaruhi suhu panas kota (Gadrani et al., 2018; Khandelwal et al., 2018; Sumunar et al., 2020).

Gambar 2 menunjukkan suhu tinggi terpusat di wilayah kota Yogyakarta dan sekitar Bantul. Suhu yang tinggi pada suatu wilayah dapat dipicu oleh padatnya lahan terbangun karena sifat termal bahan konstruksi bangunan memungkinkan perpindahan panas lebih cepat sehingga berkontribusi pada peningkatan suhu (Peres et al., 2018; Sumunar et al., 2020).

\section{Data Sebaran Spasial COVID-19}

Data COVID-19 pada kedua wilayah Yogyakarta dan Gorontalo berdasarkan data terkonfirmasi tanggal 30 September 2020. Sejak kasus COVID-19 pertama terjadi di berbagai wilayah di Indonesia, penyebarannya melampaui kapasitas kesiapsiagaan setiap pemangku kepentingan, dan dalam kurun waktu yang singkat (sekitar satu minggu) memasuki fase kritis (Hizbaron et al., 2021). Distribusi sebaran COVID19 di Provinsi Gorontalo disajikan pada Gambar 3 dan sebaran COVID-19 di DIY disajikan pada Gambar 4

Gambar 3 menunjukkan sebaran kasus terbanyak yaitu di kota Gorontalo sebagai ibu kota provinsi dan pusat kegiatan perekonomian Gorontalo, kemudian terbanyak kedua yaitu kabupaten Gorontalo yang berbatasan langsung dengan kota. Sedangkan kasus terendah di kabupaten Pohuwato. Gorontalo termasuk dalam wilayah di sulawesi yang memiliki ekstensi tingkat pemanasan tertinggi (Supari et al., 2017).

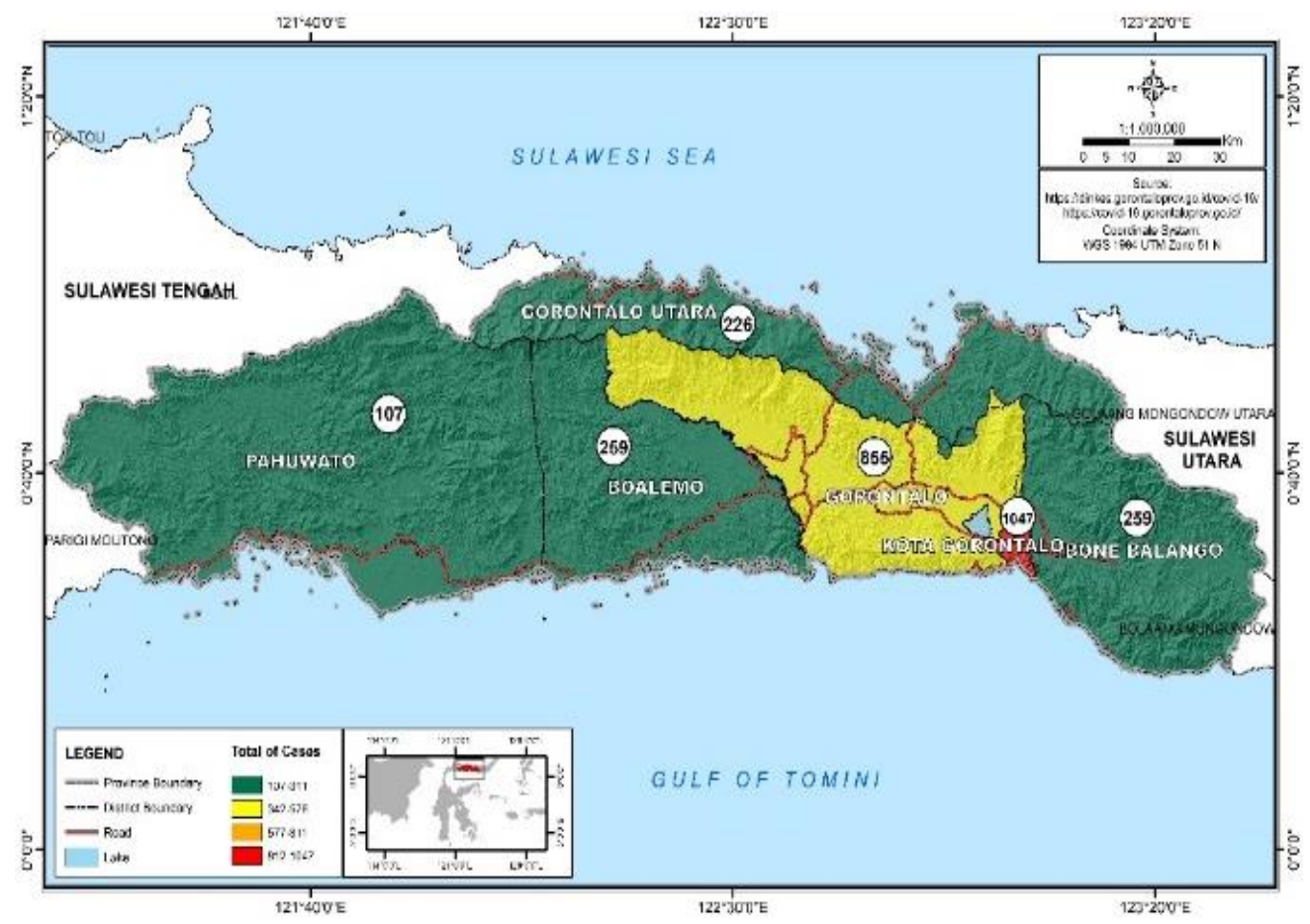

Gambar 3. Peta sebaran kasus terkonfirmasi COVID-19 terkonfirmasi di Gorontalo

(Data Per 30 September 2020)

Berdasarkan hasil LST (Gambar 1) dan korelasi LST dan jumlah kasus COVID-19 sebaran spasial COVID-19 (Gambar 3) dilakukan sebagaimana yang disajikan pada Tabel 1. Korelasi analisis perbandingan pada masing-masing hanya dilihat berdasarkan rerata LST dan total wilayah di provinsi Gorontalo untuk melihat kasus pada masing-masing wilayah. 
Tabel 1. Perbandingan LST dan COVID-19 di Provinsi Gorontalo

\begin{tabular}{lcc}
\hline Kabupaten & $\begin{array}{c}\text { Rerata LST } \\
\left.\left({ }^{\circ} \mathbf{C}\right){ }^{*}\right)\end{array}$ & $\begin{array}{c}\text { Kasus } \\
\text { terkonfirmasi**) }\end{array}$ \\
\hline Boalemo & 32,53 & 259 \\
$\begin{array}{l}\text { Bone Bolango } \\
\text { Gorontalo }\end{array}$ & 33,30 & 259 \\
$\begin{array}{l}\text { Utara } \\
\text { Kabupaten }\end{array}$ & 32,93 & 226 \\
$\begin{array}{l}\text { Gorontalo } \\
\text { Kota }\end{array}$ & 34,24 & 855 \\
$\begin{array}{l}\text { Gorontalo } \\
\text { Pohuwato }\end{array}$ & 34,24 & 1047 \\
\hline
\end{tabular}

*) Landsat 8 OLI, 19 September 2019

${ }^{* *}$ https://dinkes.gorontaloprov.go.id/covid-19/
Tabel 1 menunjukkan rerata suhu tertinggi yaitu kabupaten Gorontalo dan kota Gorontalo namun memiliki jumlah kasus terbanyak. Sedangkan suhu terendah di kabupaten Pohuwato memiliki jumlah kasus lebih sedikit. Hal ini menunjukkan bahwa suhu tidak mempengaruhi sebaran COVID-19 di provinsi Gorontalo.

Pola spasial yang agak berbeda di DIY karena jumlah kasus terbanyak bukan di pusat kota namun di kabupaten Sleman dan kabupaten Bantul yang berbatasan langsung dengan kota. Sebaran spasial COVID-19 di DIY disajikan pada Gambar 4.

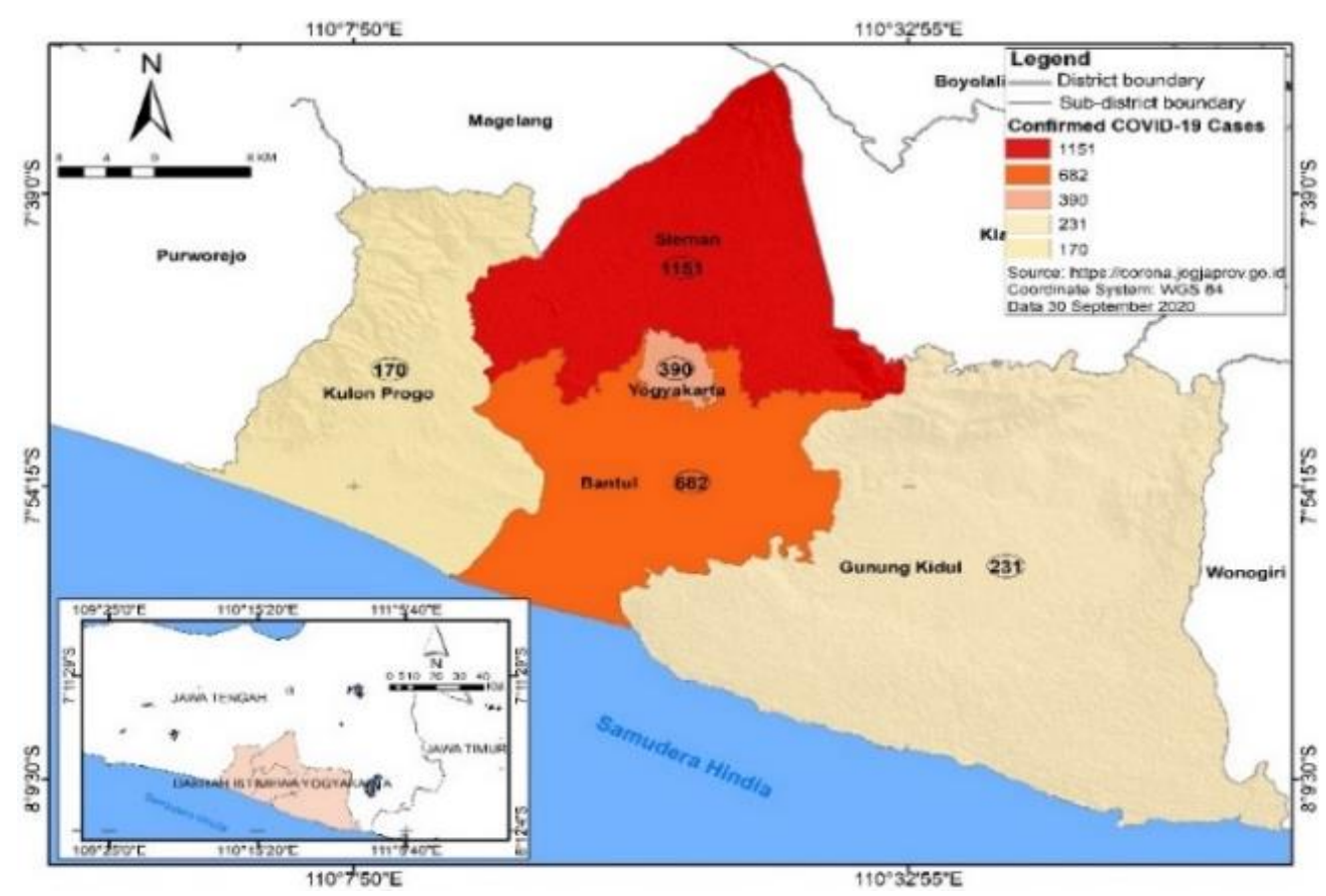

Gambar 4. Distribusi spasial COVID-19 terkonfirmasi di DIY (Per 30 September 2020)

Sleman menjadi wilayah pertama di Yogyakarta yang terkonfrmasi positif Covid-19 dua minggu setelah dua kasus nasional pertama. Sedangkan kasus terendah yaitu di kabupaten Kulonprogo, dimana Kulonprogo menjadi wilayah terdampak paling akhir di DIY. Kasus pertama di Kulonprogo baru terkonfirmasi pada tanggal 26 maret 2020. Sebaran COVID-19 di masing-masing wilayah DIY dengan suhu rerata masing-masing wilayah disajikan pada Tabel 2.

Tabel 2. Perbandingan LST dan COVID-19 di DIY

\begin{tabular}{lcc}
\hline Kabupaten & $\begin{array}{c}\text { Rerata LST } \\
\left.\left({ }^{\circ} \mathbf{C}\right){ }^{*}\right)\end{array}$ & $\begin{array}{c}\text { Kasus } \\
\text { terkonfirmasi**) }\end{array}$ \\
\hline Kulonprogo & 29,51 & 170 \\
Bantul & 32,01 & 682 \\
Sleman & 30,87 & 1151 \\
Gunungkidul & 31,24 & 231 \\
Kota & 32,72 & 390 \\
Yogyakarta & & \\
\hline
\end{tabular}

*)Landsat 8 OLI, 19 September 2019;

${ }^{* *}$ https://corona.jogjaprov.go.id/data-statistik 
Tabel 2 diatas menunjukkan kasus tertinggi yaitu di kabupaten Sleman (1151 kasus) namun suhu yang tertinggi di kota Yogyakarta $\left(32,72^{\circ} \mathrm{C}\right)$. Demikian pula suhu terendah secara spasial terdistribusi di Kulonprogo namun memiliki kasus Covid-19 terendah di DIY. Sebagaimana hasil analisis sebaran COVID-19 di Provinsi Gorontalo, sebaran COVID-19 di DIY juga tidak dipengaruhi oleh suhu. Walaupun dalam beberapa penelitian terdahulu menyebutkan bahwa terdapat korelasi positif antar suhu dan sebaran virus corona (Casanova et al., 2010; van Doremalen et al., 2013; Xie \& Zhu, 2020). Namun, tidak ada bukti yang mendukung jika cuaca lebih hangat maka jumlah kasus menurun seperti yang terjadi di Brasil pada suhu tropis berkisar antara $16,8-27,4^{\circ} \mathrm{C}$ memiliki hubungan linier negatif dengan jumlah kasus yang terkonfirmasi (Prata et al., 2020). Secara statitistik perbandingan COVID-19 di DIY dan provinsi Gorontalo disajikan pada Tabel 3.

Tabel 3. Perbandingan Statistik COVID-19 Gorontalo-DIY

\begin{tabular}{ccc}
\hline & Gorontalo & DIY \\
\hline Kasus positif & 2753 & 2643 \\
Populasi & 1.202 .631 & 3.842 .932 \\
$\begin{array}{c}\text { Kasus pertama } \\
\text { Periode kajian } \\
\text { (hari) }\end{array}$ & $10-$ Apr-20 & $15-$ Mar-20 \\
$\begin{array}{c}\text { Inf. Rate } \\
\text { Populasi } \\
\text { terpapar (\%) }\end{array}$ & 174 & 199 \\
\hline
\end{tabular}

Sumber:

1) https://corona.jogjaprov.go.id/data-statistik

2) Inf. Rate = Jumlah terpapar/ hari terpapar

Berdasarkan data COVID-19 sejak kasus pertama di kedua provinsi tersebut hingga pada tanggal 30 September 2020 menunjukkan Gorontalo memiliki kasus tertinggi dibandingkan DIY (Tabel 3), walaupun dari jumlah hari terpapar Gorontalo terhitung 174 hari sedangkan DIY lebih lama yaitu 199 hari terhitung sejak tanggal 15 Maret 2020 namun memiliki persentase terpapar lebih sedikit yaitu 0,07\% dibandingkan Gorontalo
0,23\%. Hizbaron et al., (2021) mengungkapkan bahwa DIY telah menunjukkan tata kelola adaptif terhadap pandemi COVID-19, antara lain terlihat dari akses data spasial dan non-spasial secara terbuka, mendorong keterlibatan aktif masyarakat dalam penegakan aturan baru dan regulasi yang diamanatkan oleh pemerintah nasional dan provinsi.

Tabel 3 ini menunjukkan bahwa lama periode terpapar tidak mempengaruhi pertambahan jumlah kasus COVID-19. Demikian pula kepadatan populasi bukanlah faktor penting dalam penyebaran COVID-19 (Sun et al., 2020a). Dalam hal ini faktor-faktor lain yang tidak diinvestigasi dalam penelitian ini dapat menjadi pemicu meningkatnya sebaran COVID-19 seperti kebiasaan masyarakat termasuk pekerjaan dan pendidikan. Menariknya dalam penelitian terdahulu menyatakan bahwa pendidikan dan pekerjaan dapat menjadi faktor kunci dalam eksposur resiko COVID-19 (Hanibuchi et al., 2020).

\section{Simpulan}

Persebaran COVID-19 di DIY dan Gorontalo memiliki pola yang sama dimana sebaran tertinggi mengelompok di pusat kota. Faktor-faktor yang diinvestigasi dalam penelitian yaitu suhu, lamanya waktu terpapar dan jumlah penduduk tidak menunjukkan pengaruh yang signifikan terhadap persebaran COVID-19. Gorontalo dengan suhu yang relatif lebih tinggi dibandingkan DIY memiliki persentase terpapar lebih besar dibandingkan DIY. Sebaran spasial yang mengelompok diperkotaan menunjukkan bahwa mobilitas penduduk dapat menjadi pemicu meningkatnya jumlah kasus COVID-19.

\section{Ucapan terima kasih}

Ucapan terima kasih disampaikan kepada Lembaga Penelitian dan Pengabdian, Universitas Negeri Yogyakarta yang telah memberikan dana untuk penelitian ini.

\section{Referensi}

Arif, N., Khasanah, A. N., Jaya, R., Gozan, M., \& Hendrawan, B. (2019). The Effect of Land 
Surface Temperature and Land Use on Energy System Development in Gorontalo City. Journal of Physics: Conference Series, 1179(1). https://doi.org/10.1088/17426596/1179/1/012103

Badan Pusat Statistik. 2020. Provinsi Gorontalo Dalam Angka 2020, BPS Gorontalo

Badan Pusat Statistik. 2020. Provinsi Yogyakarta Dalam Angka 2020, BPS Yogyakarta

Byass, P. (2020). Eco-epidemiological assessment of the COVID-19 epidemic in China, JanuaryFebruary 2020. Global Health Action, 13(1). https://doi.org/10.1080/16549716.2020.176 0490

Casanova, L. M., Jeon, S., Rutala, W. A., Weber, D. J., \& Sobsey, M. D. (2010). Effects of air temperature and relative humidity on coronavirus survival on surfaces. Applied and Environmental Microbiology, 76(9), 27122717. https://doi.org/10.1128/AEM.0229109

Gadrani, L., Lominadze, G., \& Tsitsagi, M. (2018). F assessment of landuse/landcover (LULC) change of Tbilisi and surrounding area using remote sensing (RS) and GIS. Annals of Agrarian Science, 16(2), 163-169. https://doi.org/10.1016/j.aasci.2018.02.005

Hanibuchi, T., Yabe, N., \& Nakaya, T. (2020). Who Is Staying Home and Who Is Not? Demographic, Socioeconomic, and Geographic Differences in Time Spent outside the Home during the COVID-19 Outbreak in Japan. SSRN Electronic Journal, 21 , 101306

https://doi.org/10.2139/ssrn.3692144

Hizbaron, D. R., Ruslanjari, D., \& Mardiatno, D. (2021). Amidst Covid-19 Pandemic: An Adaptive Disaster Governance in Yogyakarta, Indonesia. Social Sciences, 10(3), 92. https://doi.org/10.3390/socsci10030092

Khandelwal, S., Goyal, R., Kaul, N., \& Mathew, A. (2018). Assessment of land surface temperature variation due to change in elevation of area surrounding Jaipur, India. Egyptian Journal of Remote Sensing and
Space Science, 21(1), 87-94. https://doi.org/10.1016/j.ejrs.2017.01.005

Liu, T., Kang, M., Zhang, B., Xiao, J., Lin, H., Zhao, Y., Huang, Z., Wang, X., Zhang, Y., He, J., \& Ma, W. (2018). Independent and interactive effects of ambient temperature and absolute humidity on the risks of avian influenza $\mathrm{A}(\mathrm{H} 7 \mathrm{~N} 9)$ infection in China. Science of the Total Environment, 619-620(160), 13581365.

https://doi.org/10.1016/j.scitotenv.2017.11.2 26

Ma, Y., Kuang, Y., \& Huang, N. (2010). Coupling urbanization analyses for studying urban thermal environment and its interplay with biophysical parameters based on TM/ETM+ imagery. International Journal of Applied Earth Observation and Geoinformation, 12(2), 110-118. https://doi.org/10.1016/j.jag.2009.12.002

Peres, L. de F., Lucena, A. J. de, Rotunno Filho, O. C., \& França, J. R. de A. (2018). The urban heat island in Rio de Janeiro, Brazil, in the last 30 years using remote sensing data. International Journal of Applied Earth Observation and Geoinformation, 64(October 2016), 104-116. https://doi.org/10.1016/j.jag.2017.08.012

Prata, D. N., Rodrigues, W., \& Bermejo, P. H. (2020). Temperature significantly changes COVID-19 transmission in (sub)tropical cities of Brazil. Science of the Total Environment, 729, 138862.

https://doi.org/10.1016/j.scitotenv.2020.138 862

Rana, Shreema, \& Marwasta, D. (2015). Urbanisation trends in developing countries: Comparative study of Yogyakarta City and Kathmandu Valley. Journal of Natural Resources and Development, 29-36. https://doi.org/10.5027/jnrd.v5i0.04

Shi, P., Dong, Y., Yan, H., Zhao, C., Li, X., Liu, W., \& $\mathrm{He}, \mathrm{M}$. (2020). Impact of temperature on the dynamics of the COVID-19 outbreak in China. January. 
Sumunar, D. R. S., Arif, N., Hadi, B. S., \& Endro, K. (2020). Urban Energy Modeling Using Remote Sensing Approaches. International Journal of GEOMATE, 19(75), 203-208. https://doi.org/10.21660/2020.75.23161

Sun, Z., Zhang, H., Yang, Y., Wan, H., \& Wang, Y. (2020a). Impacts of geographic factors and population density on the COVID-19 spreading under the lockdown policies of China. Science of the Total Environment, 746(666), 141347. https://doi.org/10.1016/j.scitotenv.2020.141 347

Sun, Z., Zhang, H., Yang, Y., Wan, H., \& Wang, Y. (2020b). Impacts of geographic factors and population density on the COVID-19 spreading under the lockdown policies of China. Science of the Total Environment, 746, 141347.

https://doi.org/10.1016/j.scitotenv.2020.141 347

Supari, Tangang, F., Juneng, L., \& Aldrian, E. (2017). Observed changes in extreme temperature and precipitation over Indonesia. International Journal of Climatology, 37(4), 1979-1997. https://doi.org/10.1002/joc.4829

Tamerius, J. D., Shaman, J., Alonso, W. J., BloomFeshbach, K., Uejio, C. K., Comrie, A., \& Viboud, C. (2013). Environmental Predictors of Seasonal Influenza Epidemics across Temperate and Tropical Climates. PLOS Pathogens,

9(3). https://doi.org/10.1371/journal.ppat.100319 4

Van Doremalen, N., Bushmaker, T., \& Munster, V. J. (2013). Stability of middle east respiratory syndrome coronavirus (MERS-CoV) under different environmental conditions. Eurosurveillance, 18(38), 1-4. https://doi.org/10.2807/15607917.ES2013.18.38.20590

Wu, Y., Jing, W., Liu, J., Ma, Q., Yuan, J., Wang, Y., Du, M., \& Liu, M. (2020). Effects of temperature and humidity on the daily new cases and new deaths of COVID-19 in 166 countries. Science of the Total Environment, 729,

$1-7$. https://doi.org/10.1016/j.scitotenv.2020.139 051

Xie, J., \& Zhu, Y. (2020). Association between ambient temperature and COVID-19 infection in 122 cities from China. Science of the Total Environment, 724, 138201. https://doi.org/10.1016/j.scitotenv.2020.138 201

Zhang, Y., Shen, Z., Ma, C., Jiang, C., Feng, C., Shankar, N., Yang, P., Sun, W., \& Wang, Q. (2015). Cluster of human infections with avian influenza a (H7N9) cases: A temporal and spatial analysis. International Journal of Environmental Research and Public Health, 12(1),

816-828. https://doi.org/10.3390/ijerph120100816 